\title{
Importance of CPEC in the Light of Public and Private Investment from Pakistan: A Conceptual Paper Based on Archival Data
}

\author{
Muhammad Faisal Sultan \\ Assistant Professor KASBIT \& PhD Scholar KUBS-UoK \\ Anila Tahir \\ Lecturer, KASBIT \& MS Scholar, AERC-UoK \\ Soniya Naz \\ MBA Student, KASBIT
}

\begin{abstract}
CPEC is one of the most important projects for the economy of Pakistan \&also treated as crown jewels for the entire region. Massive research work has already been done on the areas which project will cover $\&$ also on opportunities and threats which project which bring etc. Although there is minimal work on the importance of CPEC on different sectors associated with the economy and there is almost no work on the realized importance of CPEC for the policy makers of Pakistan. Therefore a study is required which can provide framework for the analysis of importance the project really has for policy makers so the stake holders might consider any negative word of mouth regarding the project. Hence the major objective of this study is to drive a framework for the importance of CPEC in the light of public and private investment from Pakistan. For this purpose seventeen years data has been collected from the databank of World Bank to determine the trend of investments from Pakistan to support CPEC. Moreover data from China going global Index has also been used to answer research claims and objective regarding CPEC importance for Pakistan. Analysis highlighted that there is immense importance of FDI from China which has significantly increased after the initiation of CPEC.
\end{abstract}

Keywords: CPEC, Pak-China Relationships, FDI, Investment

DOI: $10.7176 / \mathrm{JESD} / 10-11-08$

Publication date:June $30^{\text {th }} 2019$

\section{Introduction:}

There is a lot of literature highlighting optimism for the ongoing project of CPEC in fact official definition given by government of Pakistan is also full of positive expectations from CPEC (McCartney, 2018). In reality CPEC is associated with OBOR a \$4-8 trillion Chinese initiative and thus CPEC might have some geopolitical implications in the upcoming future (Rehman \& Shurong, 2017). Study of Ahmad and Mi (2017) and Atique Ahmad Azhar Khan (2014) posits that due to CPEC China promised to invest $\$ 46$ Billion in Pakistan. This is an extraordinary FDI especially in comparison to the past record of $\$ 5$ billion which country receives in 2007-2008 (Mohiudin \& Salam, 2011) and commutative FDI of \$ seven Billion from 1970-2001 (Ahmad \& Mi, 2007).

Describing the route of CPEC Ahmad and Mi (2017) indicated that the project will pass through all the provinces of the country to reach Khunjerab pass \& China. Study of Asif (2018) indicated main parts of CPEC include Gwadar Port, industrial zones, energy, infrastructure and communication infrastructure. Study also claims that project will also aids in overcoming energy crises which will induce industrial growth and add $2 \%$ in the GDP of the country. Similarly study of Ali Mi Shah Shah and Bibi (2017) claims that from 2019 revenue generation due to CPEC will start from \$1.5 billion to \$ 1.9 billion \& will reach \$ five billion in 2022 .

\section{Problem}

Study of McCartney (2018) indicated that completion of CPEC is not possible till 2030 with worst record of Pakistan regarding ability of achieving benefit from large funded projects. On the other side Asif (2018) indicated that CPEC has also been opposed by some political parties like Baloch nationalist and ANP etc. According to study these parties are in against of CPEC even after government guaranteed regarding equal benefits of CPEC for all the provinces.

Importance of CPEC might be realized through the urge of different countries not only from Asia but also from Europe e.g. UK to join CPEC. Although India is opposing the project on the grounds that CPEC is passing through Gilgit and Biltistan which is the controversial according to India. Study further revealed that the logic behind this opposition is to please USE and Israil (CPEC: why India is opposing the project?). On the other side this is also the fact that Pakistan is not been able to attract significant investment from any other country than China (Raza, 2018). Although country has to repay an immense loan of \$ 39.83 Billion in against of total Chinese 
investment of \$26.5 Billion (Rana, 2018).

Therefore in accordance with Asif and Ling (2019) it is legitimate to indicate that realization of sensitivity for various aspects of CPEC is a potent need of recent times. This need of study is supported by voice raised by Thailand, Laos and Maldives etc regarding structure of loans from China. Furthermore cancelation of \$ 20 Billion rail project by Malaysian Prime Minister Mahathir Mohamad is also an evidence of gambling from China. All of these evidences regarding traps of Chinese investment are supplemented with the allegations that previous government did not prioritize CPEC. Hence project is not in the condition which was required for diminishing of burden from economy and residents of Pakistan. Thus a systematic study is mandatory to answer sensitive issues associated with CPEC through validating Pakistan's response in against of Chinese investment.

\section{Purpose of Study}

In association with the need of study highlighted by researchers posits the claim of Singer (1950) highlighted that the effect of FDI on developing countries are found to be negative. Griffin (1970) and Weisskopf (1972) also provide similar findings that FDI gained by developing countries from the developed countries developed countries produces negative impact on developing countries. Similarly Karikari (1992) highlighted that FDI does not improve country's productivity while Saltz (1992) indicated negative association between FDI and economic growth.

Furthermore Borensztein De Gregorio and Lee (1998) claims that FDI solely might not produce desired impact on economy until human capital of the country achieve dominant level. Although study Ali (2015) and Deng and Li (2017) indicated severe skill shortage in Pakistan's workforce as per the requirement of Chinese investors. Therefore understanding of Pakistan's response is of high importance. Hence in accordance with the study of Ullah Shah and Khan (2014) the FDI might be used to supplement local investment. Therefore keeping all these indications, postulates and points in view researchers investigates relationship between local investment in Pakistan and FDI due to CPEC.

\section{Significance}

The study must be included in pervasive studies as it is not only based on research orientation indicated by Ullah et al (2014) but also address unique concern regarding CPEC. Claim looks optimal when we consider the prior studies on the subject of CPEC as there is least work on evaluation of CPEC specially through investment pattern from Pakistan. Literature also highlighted that prior studies are related with opportunities and threats of CPEC e.g. Abid and Ashfaq (2015), Ahmad and Hong (2017) and Mirza et al (2017) etc. Therefore any attempt which might indicate CPEC preference with respect to investment made by Pakistan must be termed as pervasive one.

\section{Research Questions}

RQ1: Is there any difference in projected and estimated cost of CPEC?

RQ2: Is there enough support to believe that Pakistan is also investing in the project of CPEC in order to support FDI from China?

\section{Literature Review}

Study of Asif (2018) indicated that long-term plan of CPEC includes several projects which are in accordance with the bilateral agreements between both countries to assure win-win situation. Extending the literature Rehman and Shurong (2017) posits the importance of CPEC for Pakistan that CPEC will add 17,000 megawatt of electricity to the national grid with total investment of $\$ 34$ billion. Further breakdown of investment indicated that $\$ 4$ billion are spared for construction of Gwadar and Khunjerab pass, development of economic zones, Gwadar city and lying of fiber optic cable. Therefore it is optimal to highlight Asif (2018) that the construction of CPEC makes Pakistan role as pivotal for the entire region as total value of CPEC equals to 17\% of Pakistan's GDP for 2015 (Shah, 2017). All of these indications are further exemplified by the next claim of Shah (2017) that according to IMF in comparison to recent GDP of \$ 988 billion GDP of Pakistan will be touching \$4.2 trillion by 2020 .

Hence looks significant to believe the postulate of Asif and Ling (2019) that opponent of Pakistan are too worried due to the future strategic position of Pakistan. Further importance of CPEC can be conceptualized by Mengsheng (2015) that according to initial plan eight economic zones (EZ) are planned for different areas of Pakistan. Furthermore Khan, Sarah, Ali, Aliani, Amin and Daulat (2015) also pinpointed that some other economic zones will also be formulated due to alliance China's bank ICBC and HBL. Although to attract more investment government of Pakistan announced 34 economic zones, 29 industrial and 22 special economic zones. Therefore looks right to believe Ali et al (2017) that economic zones will not only boost economy but also generate massive employment opportunities \& diminish poverty in Pakistan. CPEC also has the ability to improve trade for Pakistan as well as for all the neighboring countries thus aid significantly in the improvement of economic conditions.

On the other side Hussain (2017) indicated that long-term plan developed by Chinese Investment Bank is thorough enough in considering risks associated with investment in Pakistan's market. In the article published in 
daily Dawn Hussain highlighted that financial plan was made after getting full awareness of Pakistan financial sector, its health and government debt market. Discussing the risks identified, Hussain indicated that politics, security and inflation are major risks associated with Pakistan's market. Thus plan also demands central as well as provincial government $s$ of Pakistan to get involved in the project for financing of activities through the issuance of sovereign guarantee bonds. Plan also indicated that limit for preferential loans and non-preferential loans fir the year is $\$ 1$ billion and $\$ 1.5$ billion respectively (Hussain , 2017). Coupled with the indication of Gul (2018) that countries like Maldives, Thailand etc all raised voice against the terms and structure of Chinese investments. Study of Gul also used the example of cancellation of \$20 billion project by newly elected prime minister of Malaysia in order to indicate debt traps in Chinese investment activities. Especially under the recent situation when newly elected finance minister of Pakistan, Mr. Asad Umer contacted IMF for the improvement of national economic crises of Pakistan.

In addition to this study of Asif and Ling (2019) also indicated that India is much concerned about the progress of CPEC and wants to disintegrate cordial tier between Pakistan and China. According to study India has already invested \$ 300 billion to disturb the project \& one of the main elements behind violence in various regions of Pakistan. Moreover India is also involved in the propagation of rumors against CPEC \& fear regarding the project in residents of Pakistan.

\section{Research Design}

The philosophy indulged with this study is ontology as the purpose of the study is highlight the importance of CPEC in the light of investment made by Pakistan to support FDI from China. This postulate is coherent with Saunders and Lewis (2012), Saunders (2012) and Saunders Lewis Thornhill and Wilson (2009) that Ontology is the philosophy of reality. Thus posit a question that "What is there?" Therefore the stance for carrying study is realism in order to determine reality of relation between groups (Pakistan and China) working together on CPEC (Taber, 2009). Moreover study uses the deductive method of research, quantitative technique \& cross-sectional time horizon to generate the body of knowledge regarding importance of CPEC (Sekaran \& Bougie \& Saunders et al., 2009).

\section{Sampling Design:}

The study is based upon data on investment activities made by China and Pakistan. Although the major concern of study is towards 17 years data for elaboration of investment activities by Pakistan in support of China.

On the contrary unavailability of factual data is the major limitation for the study, as project is still in progress therefore there is massive lacking factual data (Mirza Azem, Waheed \& Zehra 2017). Due to these facts research strategy for this study is archival (Saunders 2012 \& Saunders Lewis Thornhill \& Wilson, 2009) and to support research propositions the data was collected from World Bank (2018).

\section{Analysis and Results}

This section will present comparison of cost associated with the project (CPEC) and investment activities made by China \& Pakistan. The comparison will highlight linkage between investment activities of China and Pakistan in order to validate the claim of Hussain (2017), so to prove research postulate.

\begin{tabular}{|c|c|c|c|c|}
\hline \multicolumn{5}{|c|}{ Summary of China Pakistan Economic Corridor's Major } \\
\hline Major Categories & \# of Projects & $\begin{array}{l}\text { Estimated } \\
\text { Cost(US\$ } \\
\text { Millions) }\end{array}$ & $\begin{array}{l}\text { Projected } \\
\text { Cost(USS } \\
\text { Million }\end{array}$ & $\begin{array}{l}\text { Direct Job } \\
\text { Opportunities }\end{array}$ \\
\hline Energy & 21 & $\begin{array}{l}26,370 \text { for } \\
13,810 \mathrm{MW}\end{array}$ & $\begin{array}{l}33,000 \text { for } \\
17,045 \mathrm{MW}\end{array}$ & 71,959 \\
\hline Infrastructure(Road) & 5 & 5,341 & 5,341 & 31,474 \\
\hline Infrastructure(Rail) & 3 & 8,237 & 8,237 & 14,400 \\
\hline $\begin{array}{l}\text { Infrastructure(Optical } \\
\text { Fiber) }\end{array}$ & 1 & 44 & 44 & 1,294 \\
\hline Gawadar & 12 & 793 & $10,000-14,000$ & 77,700 \\
\hline Total & 42 & $\$ 40,784$ & $\$ 58,622$ & 196,827 \\
\hline
\end{tabular}

Table 1: Estimated and Projected Cost of CPEC (World Bank, 2018)

Table 1 indicated the major areas which CPEC will cover and the difference between their estimated and projected costs. The purpose behind indicating this difference is to posit the thought that there is a difference in prediction and reality of investment required for different areas of CPEC. Therefore postulation regarding the analysis of investments in support of CPEC is one of legitimate in the context of knowledge generation and 
research must trace further evidence in this regards.

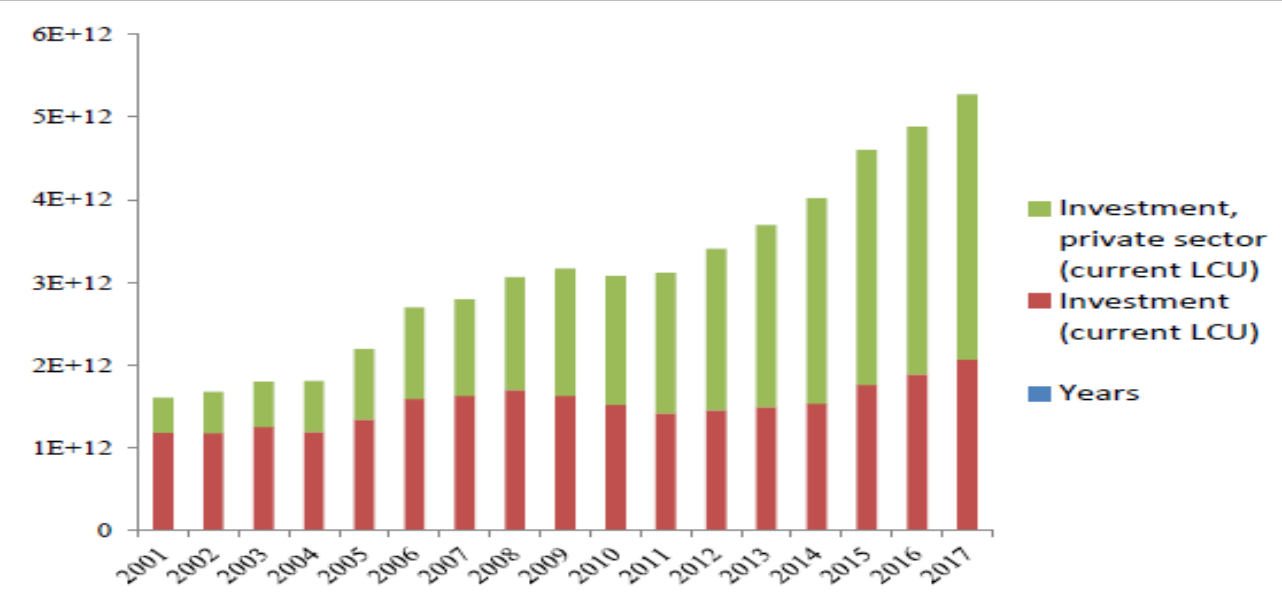

Chart 1 Pakistan investment activities after initiation of CPEC since 2015 (World Bank, 2018)

Chart 1 indicated the investment pattern from government \& private firms from 2001 to 2017 and through the pattern one can easily observed that the investment activities follow an incremental pattern. Pattern also indicating significant increase in the investment after initiation of CEPC i.e. 2015 and therefore table 2 is also affirming the postulates made by this study.

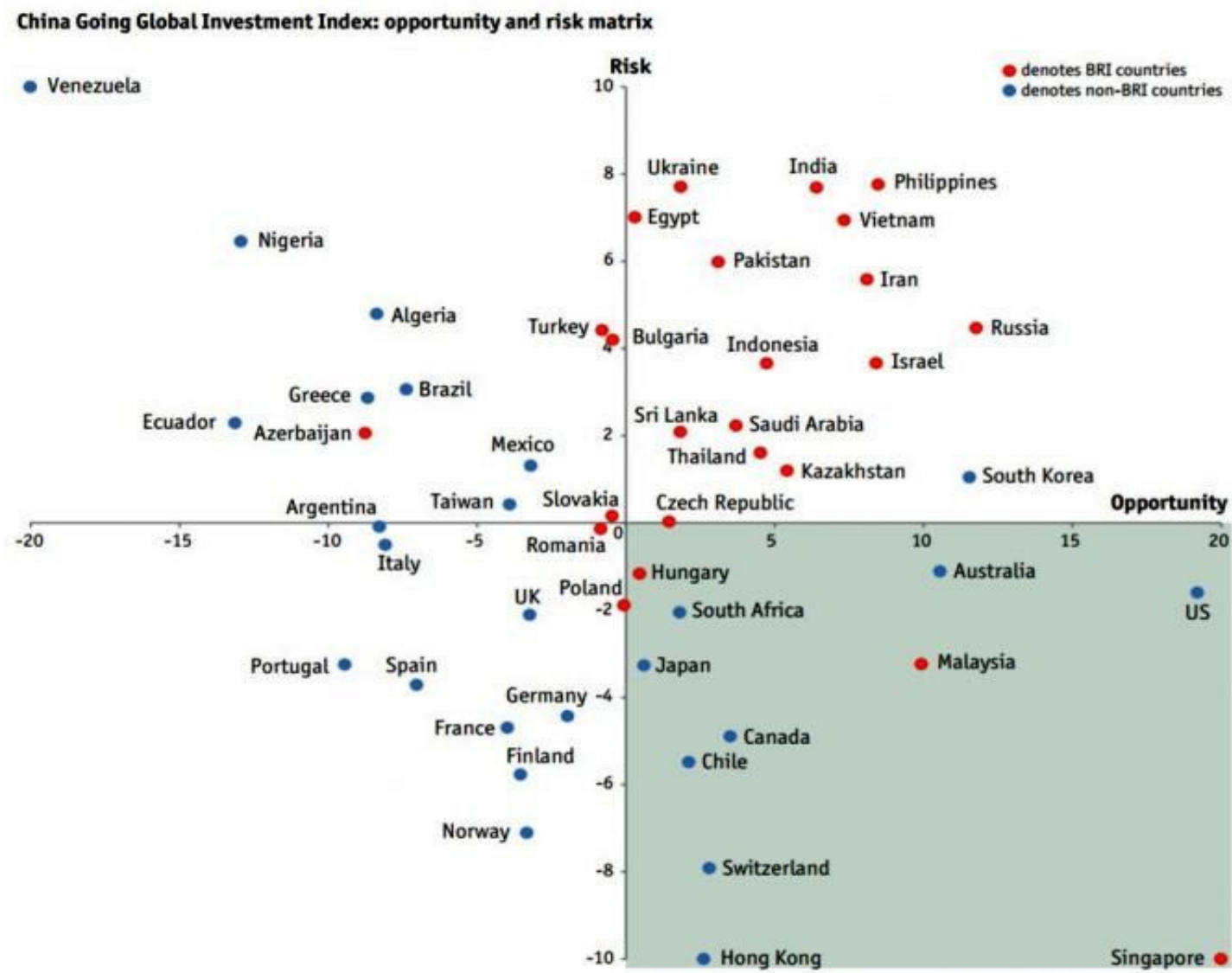

Chart 2 Matrix for opportunities and threats for investment by China all over the world. (China Going global investment index, 2016)

Chart 2 indicated various quadrants or China to invest with the $4^{\text {th }}$ quadrant (anti-clockwise) is the most appropriate for China. The chart also posits that India and Pakistan both lies in $1^{\text {st }}$ quadrant where India has more risk as well as more opportunities than Pakistan. Therefore Pakistan must invest in the support of FDI from China as per the indication of Borensztein et al (1998) in order to avoid Chinese inclination towards India or towards Bangladesh-India-China-Myanmar corridor. In addition to these elementary analyses study also uses time series data of investments of China and interment made by Pakistan in order to develop tentative relationship between 
these investment activities via help of SPSS.

Model Summary

\begin{tabular}{|l|r|r|r|r|}
\hline Model & R & R Square & \multicolumn{1}{|c|}{$\begin{array}{c}\text { Adjusted R } \\
\text { Square }\end{array}$} & $\begin{array}{l}\text { Std. Error of } \\
\text { the Estimate }\end{array}$ \\
\hline 1 & $.933^{\mathrm{a}}$ & .870 & .852 & 222.20392 \\
\hline
\end{tabular}

\section{a. Predictors: (Constant), China Investment, Pakistan}

\section{Investment}

Table 2 Model Summary therugh SPSS

Table 2 Indicating the model summary for the investment made by China in Pakistan as independent variable and invesment made by Pakistan goveronemtn and private sector as dependent variable. According to the table the value of $\mathrm{R}$ is 0.933 which means the model we develop for the study is significantly fit for statistical testing. The value of $\mathrm{R}$ is 0.870 and adjusted $\mathrm{R}$-Square is 0.853 . Therefore according to the value of $\mathrm{R}$-Square $87 \%$ deviation in dependent variable is caused by Chineese investment activits in Pakistan. Similarly decrease of 0.018 in the value of adjusted $\mathrm{R}^{2}$ indicated that much of the variaation is only because of the independent variable.

\begin{tabular}{|ll|r|r|r|r|r|}
\hline \multicolumn{1}{|l|}{} & \multicolumn{1}{c|}{$\begin{array}{c}\text { Sum of } \\
\text { Model }\end{array}$} & \multicolumn{1}{c|}{ Squares } & df & Mean Square & F & Sig. \\
\hline 1 & Regression & 4641700.256 & 2 & 2320850.128 & 47.005 & $.000^{\circ}$ \\
& Residual & 691244.154 & 14 & 49374.582 & & \\
& Total & 5332944.411 & 16 & & & \\
\hline
\end{tabular}

a. Predictors: (Constant), China Investment, Pakistan Investment

b. Dependent Variable: GDP per person employed Pakistan

Table 3 Stregth of the model

Table 3 indicated that the fit of intercept model is significantly lower than the model of the study and hence the model develop to indicate tentative realtionship is significant and applicable.

Coefficients ${ }^{a}$

\begin{tabular}{|c|c|c|c|c|c|c|}
\hline \multirow{2}{*}{\multicolumn{2}{|c|}{ Model }} & \multicolumn{2}{|c|}{$\begin{array}{c}\text { Unstandardized } \\
\text { Coefficients }\end{array}$} & \multirow{2}{*}{$\begin{array}{c}\begin{array}{c}\text { Standardized } \\
\text { Coefficients }\end{array} \\
\text { Beta } \\
\end{array}$} & \multirow[b]{2}{*}{$t$} & \multirow[b]{2}{*}{ Sig. } \\
\hline & & $\mathrm{B}$ & Std. Error & & & \\
\hline \multirow[t]{3}{*}{1} & (Constant) & 10751.129 & 426.466 & & 25.210 & .000 \\
\hline & $\begin{array}{l}\text { Pakistan } \\
\text { Investment }\end{array}$ & $1.635 \mathrm{E}-9$ & .000 & .713 & 5.224 & .000 \\
\hline & China Investment & $2.645 \mathrm{E}-9$ & .000 & .280 & 2.055 & .059 \\
\hline
\end{tabular}

\section{a. Dependent Variable: GDP per person employed Pakistan}

Table 4 indicated that there is positive relationship between Chinese investment and investment made by government and private sector of Pakistan. Moreover the t-value is significantly large which indicated that standard error is much lesser than the value of coefficient. Therefore on these grounds it is optimal to believe that the model is appropriate and have significant prediction on dependent variable (Investment by private and public sector of Pakistan).

\section{Conclusion and Managerial Implications}

According to data available from World Bank and it has been indicated that government and private sector of Pakistan are making investment in order to support FDI from China. This is not only valid for CPEC i.e. since 2015 but also for last 17-years. Thus it is legitimate to believe that government always tried to foster country's economy through supporting FDI from China. This is even indicated by Borensztein et al (1998) that government must arrange investment to support FDI which is also in the provisions of financial plan from Chinese Investment Bank (Hussian, 2017). Therefore research concludes that at present planning of Pakistan is effective enough to support the requirement of Chinese Investment Bank as well as to support Borensztein et al (1998). 


\section{Area for Future Research}

Future research might be done on tracing Pakistan investment on each aspect of CPEC i.e. Energy, Infrastructure and Gwadar. Although the data is not available from authentic sources but data from individual projects might be achieved. This will not only clarify the impact of Pakistan's investment in support of FDI from China but also will provide appropriate measure to estimate number of vacancies project (entire CPEC) will yield.

\section{References}

1. Abid, M., \& Ashfaq, A. (2015). CPEC: Challenges and opportunities for Pakistan. Journal of Pakistan Vision, 16(2), 142-169

2. Ahmad, R., \& Hong, M. (2017). China-Pakistan economic corridor and its social implication on Pakistan: How will CPEC boost Pakistan's infrastructures and overcome the challenges. Arts and Social Sciences Journal, 2, doi 10.4172/2151-6200.1000265

3. Ali, A. (2015). China Pakistan Economic Corridor (CPEC): Prospects and challenges for regional integeration. International Journal of Social Sciences and Humanity Studies, 7(1), 1-15.

4. Ali, L., Mi, J., Shah, M., Shah, S. J., \& BiBi, K. (2017).The potential socio-economic impact of china Pakistan economic corridor. Asian Development Policy Review, 5(4), 191-198.

5. Asif, M. (2018). China-Pakistan Economic Corridor: Security Concern and Role of Gwadar Port Prospect for Regional Integration. International Journal of research, 5(20), 1464-1476

6. Asif, M., \& Ling, Y. B. (2019). China Pakistan Economic Corridor (CPEC): International Media Reporting and Legal Validity of Gilgit-Baltistan. Asian Social Science, 15(2).177-187

7. Atique, Z, Khan, M.H., \&Azhar, U. (2004). The impact of FDI on economic growth under foreign trade regimes: A case study of Pakistan. The Pakistan Development Review, 43(4), 707718.https://www.crisisgroup.org/asia/north-east-asia/china/twists-and-turns-along-chinas-belt-and-road

8. Atique, Z., Ahmad, M. H., Azhar, U., \& Khan, A. H. (2004). The impact of FDI on economic growth under foreign trade regimes: A case study of Pakistan [with comments]. The Pakistan Development Review, 707718

9. Birdsall, N. \& Kinder, M. (2010). The US aid surge to Pakistan: Repeating a failed experiment: Lessons for US policymakers from the World Bank's social-sector lending in the 1990s. Centre for Global Development Working Paper, No. 205, Washington

10. Borensztein, E., De Gregorio, J., \& Lee, J. W. (1998). How does foreign Direct Investment affect economic growth? journal of international economics, 45,115-135

11. China Going Global Investment Index. (2016). The Economist Intelligence Unit Limited. 1-19

12. CPEC: Why India is opposing the project?(2017 August 2nd). Retrieved from:http://pakchinanews.pk/cpecindia-opposing-project/

13. Griffin, K. B. (1970). Foreign Capital, Domestic Savings and Growth in Less Developed Countries. Bulletin of Oxford Institute of Economics and Statistics, 32, 99-112.

14. Gul, A. (2018). China Welcomes Saudi Plans to Invest in CPEC Project with Pakistan. Retrieved from: https://www.voanews.com/a/china-welcomes-saudi-plans-invest-cpec-project-with-pakistan/4604946.html

15. Gul, A. (2018, October 8th).China Welcomes Saudi Plans to Invest in CPEC Project With Pakistan. Retrieved from: $\quad$ https:/www.voanews.com/a/china-welcomes-saudi-plans-invest-cpec-project-withpakistan/4604946.html

16. Hussain, E. (2017). China-Pakistan economic corridor: will it sustain itself?. Fudan Journal of the Humanities and Social Sciences, 10(2), 145-159.

17. Hussain, K., (2017, May 15th). CPEC Master Plan revealed. The Daily Dawn, https://epaper.dawn.com/DetailImage.php?StoryImage=15 052017001005

18. Karikari, J. A. (1992). Causality between direct foreign investment and economic output in Ghana. Journal of Economic Development, 17(1), 7-17.

19. Khan, M. F., Sarah, K., Ali, M. S., Aliani, F., Amin, M. A. and Daulat, A., (2015). CPEC: A big impetus for growth and investment, Economics, Pakistan Strategies. KASB Securities.

20. McCartney, M. (2018). The China-Pakistan Economic Corridor (CPEC): Considering Contemporary Pakistan through Old-Fashioned Economics and Historical Case Studies. The Lahore Journal of Economics, 23(2), 1948.

21. Mengsheng, T. (2015).How to design the layout of the China-Pakistan economic corridor.Blue Chip.

22. Mirza R. I., Azem, K., Waheed, N., and Zehra, K. (2017). China Pakistan Economic Corridor - An Economy booster for Pakistan, Journal of Developing Country Studies, 7(3), 41-49

23. Mohiudin, S. A., \& Salam, M. A. (2011). Determinants of foreign direct investment in Pakistan. Journal of Independent Studies and Research, 9(1), 117-124

24. Rahman, S. U., \& Shurong, Z. (2017). Analysis of Chinese Economic and National Security Interests in China Pakistan Economic Corridor (CPEC) under the Framework of One Belt One Road (OBOR) Initiative. Arts 
and Social Sciences Journal, 8(4), 1-7.

25. Rana, S., (2018, December 26th). Pakistan to pay China $\$ 40$ b on $\$ 26.5$ b CPEC investments in 20 years. The Express Tribune, https://ribune.com.pk/story/1874661/2-pakistan-pay-china-40-billion-20-years/

26. Raza, M. M., (2018, June 29th). What Can Pakistan Do to Attract More Investment? The Diplomat, https://thediplomat.com/2018/06/what-can-pakistan-do-to-attract-more-investment/

27. Saunders, M. N. (2012). Choosing research participants. Qualitative organizational research: Core methods and current challenges, 35-52

28. Saunders, M. N., \& Lewis, P. (2012). Doing research in business \& management: An essential guide to planning your project. Pearson.

29. Saunders, M., Lewis, P., Thornhill, A., \& Wilson, J. (2009). Business research methods. Financial Times, Prentice Hall: London.

30. Sekaran, U., \& Bougie, R. (2016). Research methods for business: A skill building approach. John Wiley \& Sons.

31. Shah, F. (2017, February 23rd). Does the China-Pakistan economic corridor worry India?, https://www.aljazeera.com/indepth/features/2017/02/china-pakistan-economic-corridor-worry-india170208063418124.html

32. Singer, H. W. U. S. (1950). Gains and losses from trade and investment in under developed countries. American Economic Review, 40(2), 473-85

33. Taber, K. S. (2009). Progressing science education: Constructing the scientific research programme into the contingent nature of learning science (Vol. 37). Springer Science \& Business Media.

34. Ullah, I., Shah, M., \& Khan, F. U. (2014). Domestic investment, foreign direct investment, and economic growth nexus: A case of Pakistan. Economics Research International, http://dx.doi.org/10.1155/2014/592719

35. Weisskopf, T. E. (1972). The impact of foreign capital inflow on domestic savings in underdeveloped countries. Journal of international Economics, 2(1), 25-38.

36. World Bank. International Economics Dept. Development Data Group. (2018). World development indicators. World Bank. 